\title{
若年者口腔癌症例の検討
}

$\begin{array}{lrr}\text { 吉野 } & \text { 泰弘・岡本 } & \text { 美孝・江戸 雅孝 } \\ \text { 花沢 } & \text { 秀・戸川 } & \text { 清 }\end{array}$

\section{Oral Cavity Gancer in Young Adults}

\author{
Yasuhiro Yoshino, Yoshitaka Okamoto, Masataka Edo, \\ Shigeru Hanazawa and Kiyoshi Togawa
}

(Akita Univerisity School of Medicine)

\begin{abstract}
A retrospective study was performed on 25 young adults (40 years old or younger) with oral cavity carcinoma at Akita University School of Medicine between June, 1976 and March, 1991. Most of the patients had tongue cancer (20 cases), and the others had cancer of the lower gum (2), upper gum (1), oral floor (1) and hard plate (1). On presentaiton, 5 cases were clinically $\mathrm{T}_{1}, 12 \mathrm{~T}_{2}, 7 \mathrm{~T}_{3}$ and $1 \mathrm{~T}_{4}$. Cervical lymph node swelling $\left(\mathrm{N}_{1-3}\right)$ was seen in 8 cases $(32.0 \%)$. Combined treatment of surgery after radio-chemotherapy was performed in 24 cases without one case of clear cell carcinoma of the hard plate, which was treated by only surgery. Recurrent lymph node metastasis during or after the treatment was observed in 4 of the $17 \mathrm{~N}_{0}$ cases, and pathological lymph node metastasis was observed in 1 patient. They were treated with radical neck dissection, but 2 patients died. There was a high incidence of nodal metastasis and recurrence in young adults, so its control is very important for the treatment. The 5-year survival rate in young adults was $79.8 \%$ in oral cavity cancer, and $74.7 \%$ in tongue cancer, which are similar to the rates in older patients. The prognosis of oral cavity cancer in young adults was not any worse than in older patients.
\end{abstract}

Key words: oral cavity cancer, young adults, clinical course, prognosis

はじめに

舌を含む口腔悪性腫瘍は, 他臓器における悪 性腫瘍と同様に 50 ～60歳代のいわゆる癌年龄層 に多く発症する。一方, 外国文献に多く用いら れるように，40歳以下の年齢を若年者とすると， 口腔癌症例に占める若年者の割合は約 $10 \%$ 前後 であり, 決して高くはない。一般に若年者癌は, 進行が速く，転移しやすく，予後不良と言われ ているが，今回我々は当科で一次治療を行なっ た舌を含む若年者口腔癌症例を対象とし，その
転移様式, 臨床経過, 照射 - 化学療法効果, 抒 よび予後について検討し，さらに治療上の問題 点について若干の検討を加えた.

$$
\text { 対 象 }
$$

1976年 4 月から1991年 3 月までの過去15年間 に，当科で一次治療を行なった40歳以下の舌を 含む若年者口腔癌症例は25例であり，これらを 対象として検討を加えた. 年齢分布では, 20 歳 以下 0 例, 21 30歳 6 例, 31 40歳19例で, 汪 とんどが31〜40歳の症例であった. 発生部位で 
は, 辞が20例と最も多く, 次いで下歯肉 2 例, 上歯肉・口腔底・硬口蓋各 1 例であった（表 1 )。組織型では，上歯肉の 1 例に粘表皮癌, 硬口蓋癌の 1 例に明細胞癌を認めたが，他の 23 例は全て扁平上皮癌であった（表 2 ）。 TN 分 類では, $\mathrm{T}_{1} 5$ 例, $\mathrm{T}_{2} 12$ 例, $\mathrm{T}_{3} 7$ 例 $\mathrm{T}_{4} 1$ 例で, $\mathrm{N}_{0}$ 17例， $\mathrm{N}_{1-3} 8$ 例である（表 3 ）.

\section{結果}

(1) 転移様式

若年者口腔癌 25 症例の $\mathrm{TN}$ 分類を見ると， $\mathrm{T}_{1} \cdot \mathrm{T}_{2}$ 症例16例のうち, $\mathrm{N}_{(+)}$症例は 1 例に認 めるのみであったが, $\mathrm{T}_{3} \cdot \mathrm{T}_{4}$ 症例では 9 例中

表 1 若年者口腔癌の症例構成 (1976. 4 1991. 3)

\begin{tabular}{cr}
\hline \hline 舌 & 20例 \\
下歯肉 & 2例 \\
上粎肉 & 1例 \\
口腔底 & 1例 \\
硬口蓋 & 1例 \\
\hline 計 & 25 例
\end{tabular}

表 2 若年者の口腔癌の組織型

\begin{tabular}{lr}
\hline \hline 扁平上皮癌 & 23例 \\
粘表皮癌 & 1例 \\
明細胞癌 & 1例 \\
\hline \multicolumn{1}{c}{ 計 } & 25例
\end{tabular}

表 3 若年者口腔癌症例の $\mathrm{TN}$ 分類

(1976. 4〜1991. 3)

\begin{tabular}{|c|c|c|c|c|c|}
\hline & $T_{1}$ & $\mathrm{~T}_{2}$ & $\mathrm{~T}_{3}$ & $\mathrm{~T}_{4}$ & TOTAL \\
\hline $\mathrm{N}_{0}$ & 5 & 11 & 1 & 0 & 17 \\
\hline$N_{1}$ & 0 & 0 & 3 & 0 & 3 \\
\hline $\begin{array}{l}N_{2} \\
\left(\begin{array}{l}a \\
b \\
c\end{array}\right)\end{array}$ & 0 & $\begin{array}{c}1 \\
\left(\begin{array}{l}0 \\
1 \\
0\end{array}\right)\end{array}$ & $\left.\begin{array}{c}3 \\
(0 \\
2 \\
1\end{array}\right)$ & 0 & 4 \\
\hline $\mathrm{N}_{3}$ & 0 & 0 & 0 & 1 & 1 \\
\hline TOTAL & 5 & 12 & 7 & 1 & 25 \\
\hline
\end{tabular}

8 例が $\mathrm{N}_{(+)}$症例であり, 進行すると高頻度に リンパ節転移が出現することがうかがえる。一 方, $\mathrm{N}_{0}$ 症例の頸部転移・再発について検討し てみると， $\mathrm{T}_{2} \mathrm{~N}_{0}$ 症例10例のらち，照射中，ま たは術後に頸部転移が出現した例が 4 例に認め られ，また， $\mathrm{T}_{1} \mathrm{~N}_{0}$ 症例の一例は血管吻合のた めに切除した組織中に組織学的にリンパ節転移 が発見されている．すなわち， $\mathrm{N}_{0}$ 症例17例中 5 例（29.4\%）に頸部転移が出現したこととな り，同様の検討を行なった $\mathrm{N}_{0}$ 舌癌症例63例の 頸部転移出現率 $15.9 \%$ と比較して有意に高い比 率であった。

遠隔転移は 3 例 (12.0\%) 飞認められたが， いずれの症例も頸部転移を伴って扣り，多くの 頭頸部癌にみられるように, 頸部転移 $\rightarrow$ 遠隔転 移という転移様式が認められた。遠隔転移の出 現率は, 対照とした舌癌症例130例の遠隔転移 出現率 $10.0 \%$ と比較して差はなかった。

(2) 臨床経過

当科に拈ける口腔扁平上皮癌の治療は，原則 として 5-FU $250 \mathrm{mg} \times$ 週 3 回併用, Linac X線 $60 \mathrm{~Gy}$ 術前照射後, 初診時の進展範囲に応じて 腫瘍切除するといら，一貫した複合療法を行な ってきた．若年者に扣いてもこの治療方針に従 って治療を行なって拉り，今回検討した 25 症例 のらち，手術のみを施行した硬口蓋癌 $\left(\mathrm{T}_{1} \mathrm{~N}_{0}\right.$, 明細胞癌), 掞よび術前照射 $30 \mathrm{~Gy}$ で手術を施 行した上雪肉癌（ $\mathrm{T}_{1} \mathrm{~N}_{0}$, 粘表皮癌) の 2 例を除 き, 他の23例に対して複合療法を行なった． 7 例に再発が認められ，いずれも舌癌症例で, 対 側に転移した 1 例を含めて頸部再発 5 例，局所

表 4 再発例・死亡例の検討

\begin{tabular}{|c|c|c|}
\hline 1. 舌 & $\mathrm{T}_{2} \mathrm{~N}_{0}$ & 顏部転移 $\rightarrow$ 䅡部郭清術 $\rightarrow$ 䅡部再発 $\rightarrow$ 死亡 \\
\hline 2. 舌 & $\mathrm{T}_{2} \mathrm{~N}_{0}$ & 頝部転移 $\rightarrow$ 䅡部郭清術 $\rightarrow$ 生存 \\
\hline 3. 舌 & $\mathrm{T}_{2} \mathrm{~N}_{0}$ & 䅡部転移 $\rightarrow$ 頝部郭清術 $\rightarrow$ 生存 \\
\hline 4. 舌 & $\mathrm{T}_{2} \mathrm{~N}_{0}$ & $\begin{array}{c}\text { 照射中に頚部転移出現 } \rightarrow \text { 䅡部郭清術併施 } \\
\quad \rightarrow \text { 頚部再発, 遠隔転移 } \rightarrow \text { 死亡 }\end{array}$ \\
\hline 5. 舌 & $\mathrm{T}_{3} \mathrm{~N}_{1}$ & 局所再発 $\rightarrow$ 死亡 \\
\hline 6. 舌 & $\mathrm{T}_{3} \mathrm{~N}_{2} \mathrm{~b}$ & 対側䅡部転移 $\rightarrow$ 頝部郭清術 $\rightarrow$ 遠隔転移 $\rightarrow$ 死亡 \\
\hline 舌 & $\mathrm{T}_{4} \mathrm{~N}_{3}$ & 遠隔転移 $\rightarrow$ 死亡 \\
\hline
\end{tabular}


再発，および遠隔転移それぞれ 1 例であった （表 4). 頸部再発に対しては全例に頸部廓清術 を施行し，2 例は救命し得たが，2 例は頸部の 制御ができずに死亡，1 例はさらに遠隔転移を 来し，死亡した。 また，局所再発，遠隔転移の 2 例は CDDP を中心とした化学療法を行なっ たが，十分な効果が得られず死亡した。

代表的な 2 例を提示する。

症例 4.30歳, 男性.

初診時腫瘍最大径が $2 \mathrm{~cm}$ をわずかに越党る 程度の $\mathrm{T}_{1}$ に近い $\mathrm{T}_{2} \mathrm{~N}_{0}$ 舌癌症例である (図 1 ). 組織学的には軽度の角化傾向を有する中分化型

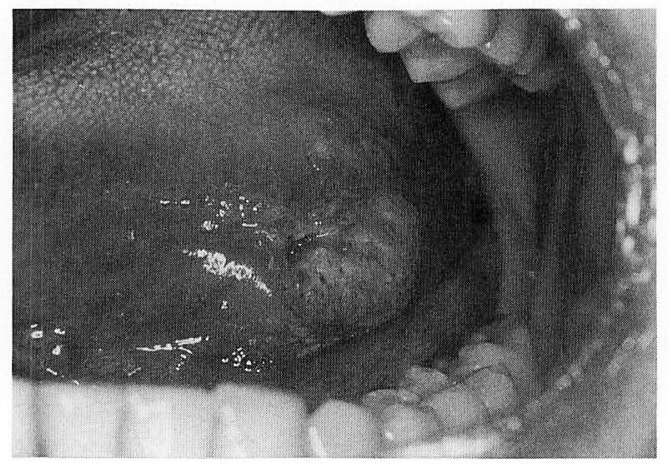

図 1 症例 4

腫瘍最大径が $2 \mathrm{~cm}$ をわずかに 越光る $\mathrm{T}_{1}$ に近い $\mathrm{T}_{2}$ 舌癌症例

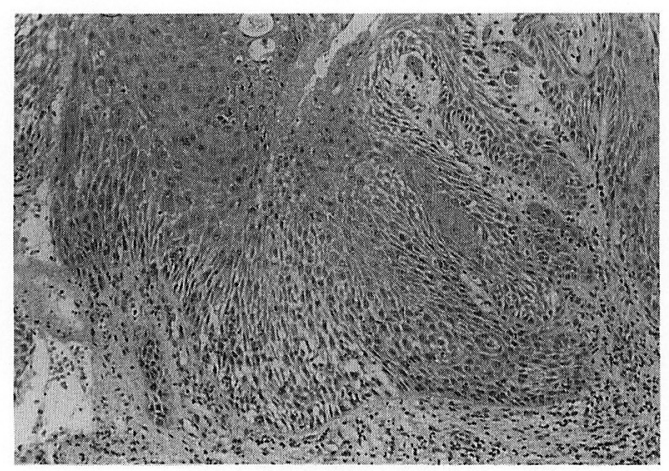

図 2 症例 4

組織学的には, 悪性度の低い中分化型扁平上皮癌. $(\mathrm{H}-\mathrm{E}$ 染色 $\times 40)$
の扁平上皮癌で，浸潤傾向少なく，境界比較的 明瞭, 細胞配列も整然として括り, 組織学的悪 性度は低いように見受けられた（図 2 ）。当科 の治療方針に従い術前照射を開始したが，照射 中に左中深頸部に硬いリンパ節を触知するよう になり，徐々に増大傾向を示すため，手術時に 頸部廓清術を併施した。組織学的に頸部転移が 明らかとなり, 術後化学療法として Pepleomycin-CDDP による化学療法を 3 クール施行した が， 3 クール目施行直後に頸部再発が明らかと なり,さらに放射線療法, 化学療法を追加した が制御でさず，遠隔転移も出現し，不幸な経過

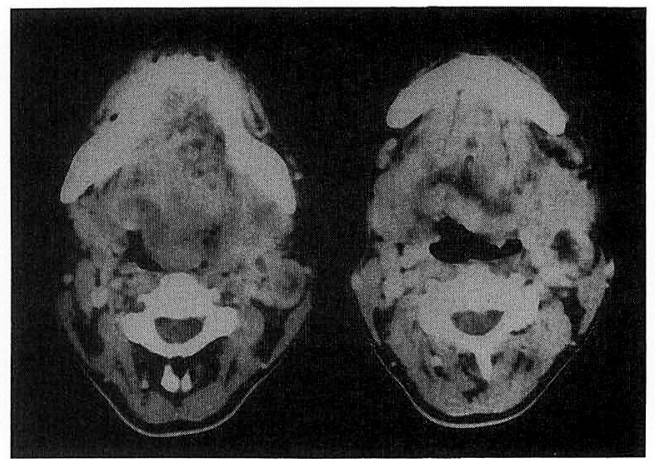

図 3 症例 7

舌根部に至るまで舌の大部分を腫瘍が占め，両側 頸部にリンパ節転移を伴った高度進展例

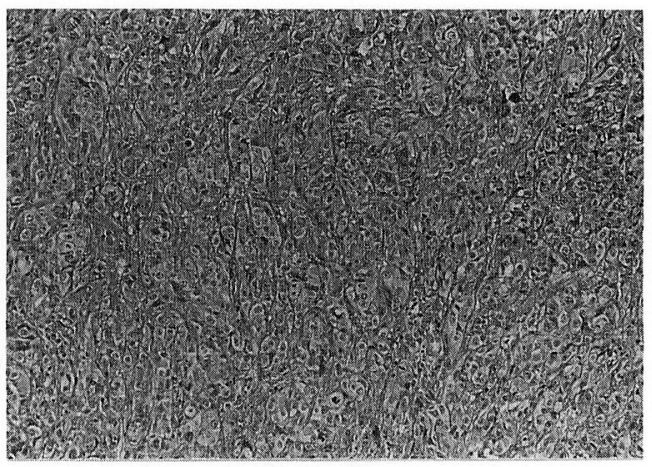

図 4 症例 7

組織学的には，未熟な細胞が敷石状に配列した， 悪性度の高い低分化型扁平上皮癌.

$(\mathrm{H}-\mathrm{E}$ 染色 $\times 40)$ 
をたどる。

症例 7 . 36歳, 女性.

初診時 $\mathrm{T}_{4} \mathrm{~N}_{3}$ 舌癌症例で, 舌の硬結を自覚後 3 カ月で急速に腫瘍が増大し，当科受診時は右 舌縁にわずかに正常と思われる舌組織を残すの みであった． CT 上, 舌根に至るまで舌のほと んどの部分を占拠する大きな腫瘍が認められ， 両側頸部に内部が壊死に陥った大さなリンパ節 を伴っていた（図 3 ). 組織学的には角化傾向 を認めない，浸潤傾向著しく，敷石状の配列を 示す未熟な細胞増殖を認める，悪性度の高い低 分化型扁平上皮癌であった（図 4 ）．Ga シンチ グラム上，転移を疑わせる所見はなかったが，

表 5 原発巣照射効果と予後

\begin{tabular}{c|cccc|c}
\hline \hline & \multicolumn{3}{|c|}{ 下 里 } & 分 類 & 計 \\
& IIa & IIb & III & IV & (1) \\
\hline $\mathrm{T}_{1}$ & & & & 2 & 2 \\
$\mathrm{~T}_{2}$ & $4(1)$ & 1 & $3(1)$ & 4 & $12(2)$ \\
$\mathrm{T}_{3}$ & $3(1)$ & 1 & 1 & 2 & $7(1)$ \\
$\mathrm{T}_{4}$ & & $1(1)$ & & & $1(1)$ \\
\hline 計 & $7(2)$ & $3(1)$ & $4(1)$ & 8 & $22(4)$ \\
& & & \multicolumn{4}{c}{ ( ) は死亡症例 }
\end{tabular}

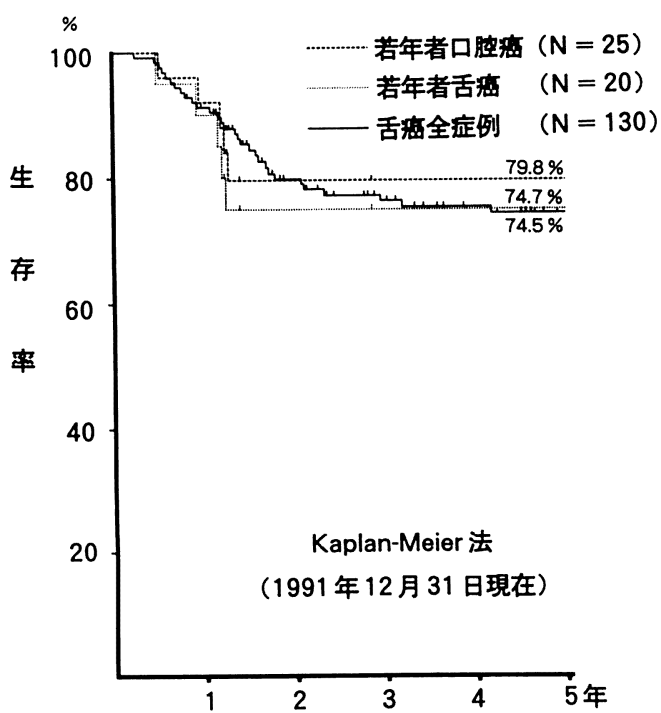

図 5 若年者口腔癌・舌癌の累積 5 年生存率
微小転移の可能性がきわめて高いため，5-FU に加光て CDDP $40 \mathrm{mg} /$ body 2 回併用しつつ, 術前照射 $60 \mathrm{~Gy}$ 施行した. 手術は下顎・喉頭を 含めて舌拡大全摘し, 両側頸部廓清術を併施す ることによって局所および頸部のコントロール は可能であったが, 術後 2 力月目に肺・骨転移 が明らかとなり，化学療法を行なったが十分な 効果が得られず，不幸な経過をたどる．治療開 始後 6 力月, 発症後 9 力月と, 急速な経過をた どった 1 例であった.

（3）照射 ·化学療法効果

複合療法を行なった若年者口腔扁平上皮癌 23 症例のらち，22症例に打いて原発巣の照射・化 学療法効果を判定し得た (表 5 ). 効果の判定 は下里の分類に従った. 5-FU 併用, $60 \mathrm{~Gy}$ の 全線量照射で, 下里III・Nの良好な効果が得ら れた例は12例（54.5\%）で，特に腫瘍の小さな $\mathrm{T}_{1} \cdot \mathrm{T}_{2}$ 症例では14例中 9 例 $(64.3 \%)$ に良好 な効果が得られた。しかし, 逆に, $\mathrm{T}_{1} \cdot \mathrm{T}_{2}$ 症 例でも $35.7 \%$ に腫瘍残存があることとなり，外 照射・化学療法のみで根治を目指すには限界が あると思われる。

照射・化学療法効果と予後との関連では, 下 里 II a II b の効果不良群で10例中 4 例 $(40.0$ \%) が死亡, 下里 III ・ $\mathrm{N}$ の効果良好群で12例中 1 例 (8.3\%) が死亡して扣り, 照射・化学療 法効果が良いほど予後良好であった。すなわち， 腫瘍径の小さなものほど照射効果が良く予後も 良いという結果であった。

（4）予後について

若年者口腔癌の予後が悪いか否かといら問題 であるが，今回検討した 25 症例についてみると 累積 5 年生存率は $79.8 \%$ で, 舌癌 20 症例をとっ てみても $74.7 \%$ と，注満足できる結果であっ た.これは対照とした 40 歳以上の舌癌症例 110 例の累積 5 年生存率 $75.6 \%$ と比較して差はなか った（図 5 ).

\section{考察}

若年者口腔癌の特徵として, 頸部転移の頻度 が高いことが報告されて拈り， Randall ら1)は 
舌癌の $67 \%$ に, Lund 52) は43\%, Cusumano ら゙) は50\%に頸部転移を認めたと報告している。 我々の検討では, 初診時に頸部転移を認めた例 は25例中 8 例 $(32.0 \%$ ）と，これらの報告と比 較して高くはないが， $\mathrm{N}_{0}$ 症例に执ける頸部再 発例，扣よび組織学的頸部転移例を含めると， 25例中13例 $(52.0 \%$ ）に頸部転移が認められた こととなる.これは，同様の検討を行なった 40 歳以上の舌癌症例 110 例の頸部転移出現率 47.3 \%よりもやや高い数值であった. しかし，若年 者口腔癌症例では約 $2 / 3$ が $T_{1}, T_{2}$ 症例であっ たことを考慮に入れると，やはり高率に頸部転 移を来しやすいと言えるだろう。特に， $\mathrm{T}_{2} \mathrm{~N}_{0}$ 症例での頸部再発の頻度が高く，また，頸部再 発例では頸部廓清術を行なっても制御できたも のは 4 例中 2 例 $(50.0 \%)$ と，必ずしも良いわ けではない，原発巣の組織学的悪性度が低くて も頸部転移を来す例が認められており，治療後 の厳重な経過観察が必要なのは言らまでもない が，若年者では予防的頸部廓清術や，予防的頸 部照射についても一考する必要があるだろう。

また，照射・化学療法の検討から，腫瘍径が 小さい汪ど効果が良く予後も良いといら結果で あったが，このことから，やはり他臓器の癌と 同様，早期発見・早期治療が治療成績向上飞欠 かせないものであると言える。

予後に関しては，一般的には若年者の癌は進 行が速く，転移しやすく，予後不良であると言 われているが，頭頸部癌に関しては必ずしもそ らではなく，特に舌・口腔癌に関しては同程度， ないしはさほど悪くない(4) 6) とする報告が多い， 当科の治療成績に扮いても, 若年者口腔癌 25 症 例の累積 5 年生存率は $79.8 \%$ と，注満足でき るものであった．今回検討した症例では，合併 症が少なく他因死が 1 例もなかったこと，およ び $\mathrm{T}_{1}, \mathrm{~T}_{2}$ のstage の低い症例が多かったことが 理由として挙げられるだろう. 稀に急速な進行 を示し, 頸部転移・遠隔転移を来して不幸な経 過をたどるきわめて予後不良な症例があること が指摘されている4)5) が，現在のところこのよ
らな症例に対する有効な治療法は無く，今後の 課題であると言える. 照射療法, 化学療法の上 手な組み合わせに加えて，積極的に手術を行な らことにより，救命し得る症例は増すものと思 われる。

若年者癌治療に際して留意すべき点として， 患者は手術療法による曣下障害や構音障害等の 社会的ハンディを生涯にわたって背負っていか なければならないこと，また，照射療法・化学 療法による二次癌の発生の可能性や生殖能に与 える影響などが挙げられ，疾病の管理のみでな く社会生活に扣いても十分な援助と適切なアド バイスが必要となる，幸いにして，当科で治療 を行ない，救命し得た若年者口腔癌症例は，注 とんどが社会復帰して拈り，これは $\mathrm{T}_{1} \cdot \mathrm{T}_{2}$ の 進行していない症例が多かったこともあるが， 若年者では嚥下・咀嚼・構音等の訓練に対する 姿勢が積極的であり，社会適応が早いことが理 由として挙げられる。 また，二次癌の発生した 症例も現在のところ認められていない，救命を 第一に考光，積極的に手術を含めた治療を行な らことが最善の方法であると考える。

\section{まとめ}

1. 過去15年間に当科で一次治療を行なった 40歳以下の若年者口腔癌症例25例について検討 した. 舌癌症例が 20 例と多数を占め, 組織学的 には洼とんどが扁平上皮癌であった．

2. 進行すると高率にリンパ節転移を来し, 頸部再発の頻度が高く, 頸部の制御が治療上の 重要なポイントであると考えられた。

3 . 若年者口腔癌症例の全体的な予後は概し て良好であった．しかし，急速な進行を示す予 後不良な例があり, 今後の治療の課題である.

4. 他藏器の癌と同様, 早期発見 - 早期治療 が治療成績向上に不可欠である.

\section{参考文献}

1) Randall CJ and Shaw $\mathrm{HJ}$ : Malignant tumours of the tongue in young adults. J Laryngol Otol $100: 1295 \sim 1298,1986$.

2) Lund VJ and Howard DJ : Head and neck 
cancer in the young ; a prognostic conundrum? J Laryngol Otol 104 : 544 548, 1990.

3) Cusumano RJ and Persky MS : Squamous cell carcinoma of the oral cavity and oropharynx in young adults. Head Neck Surg $10: 229 \sim 234$, 1988.

4) 高原哲夫, 藤谷哲造, 井上建造, 他 : 若年者 (40 歳未満）に拔ける舌・腔・中咽頭癌の臨床像 と治療成績. 頭頸部腫瘍 $10: 181,1984$.
5）吉野邦俊, 佐藤武男, 宮原 裕, 他 : 若年者の 頭頸部癌について. 頭頸部腫煌 $11: 376,1985$.

6) Jones JB, Lampe HB and Chewng HW : Carcinoma of the tongue in young patients. $\mathrm{J}$ Otolalyngol $18:$ 105 108, 1989.

$$
\left(\begin{array}{l}
\text { 別刷請求先 : 吉野泰弘 } \\
\mathbf{T} 010 \text { 秋田市本道1-1-1 } \\
\text { 秋田大学医学部耳鼻咽喉科学教室 }
\end{array}\right)
$$

